\title{
Fishes of the Taquari-Antas river basin (Patos Lagoon basin), southern Brazil
}

\author{
Becker, FG. ${ }^{a *}$, De Fries, LCC. ${ }^{b}$, Ferrer, $J^{b}{ }^{b}$ Bertaco, VA. ${ }^{b}$, Luz-Agostinho, KDG. ${ }^{c}$, \\ Silva, JFP. ${ }^{d}$, Cardoso, AR..$^{e}$ Lucena, ZMS..$^{f}$ and Lucena, CAS..$^{f}$
}

a'Laboratório de Ecologia de Paisagem, Departamento de Ecologia, Universidade Federal do Rio Grande do Sul - UFRGS, Av. Bento Gonçalves, 9500, Setor 4, Prédio 43422, CP 15007, CEP 91501-970, Porto Alegre, RS, Brazil

'Laboratório de Ictiologia, Departamento de Zoologia, Universidade Federal do Rio Grande do Sul - UFRGS,

Av. Bento Gonçalves, 9500, Setor 4, Prédio 43435, CEP 91501-970, Porto Alegre, RS, Brazil

'Limnobios Consultoria em Ambientes Aquáticos, Av. Pioneiro Alicio Arantes Campolina, 1223A, CEP 87020-750, Maringá, PR, Brazil

dJPSBIO Consultoria Ambiental, Estrada Francisca de Oliveira Vieira, 796, CEP 91780-050, Porto Alegre, RS, Brazil eSetor de Ictiologia, Museu de Ciências Naturais, Fundação Zoobotânica do Rio Grande do Sul,

Av. Dr. Salvador França, 1427, CEP 90690-000, Porto Alegre, RS, Brazil

fSetor de Ictiologia, Museu de Ciências e Tecnologia, Pontifícia Universidade Católica do Rio Grande do Sul - PUCRS, Av. Ipiranga, 6681, CP 1424, CEP 90619-900, Porto Alegre, RS, Brazil

*e-mail: fgbecker@ufrgs.br

Received November 29, 2011 - Accepted March 23, 2012 - Distributed February 28, 2013

(With 4 figures)

\begin{abstract}
The aquatic habitats of the Taquari-Antas river basin (in the Patos Lagoon basin, southern Brazil) are under marked environmental transformation because of river damming for hydropower production. In order to provide an information baseline on the fish fauna of the Taquari-Antas basin, we provide a comprehensive survey of fish species based on primary and secondary data. We found 5,299 valid records of fish species in the basin, representing 119 species and 519 sampling sites. There are 13 non-native species, six of which are native to other Neotropical river basins. About $24 \%$ of the total native species are still lacking a taxonomic description at the species level. Three native long-distance migratory species were recorded (Leporinus obtusidens, Prochilodus lineatus, Salminus brasiliensis), as well as two potential mid-distance migrators (Parapimelodus nigribarbis and Pimelodus pintado). Although there is only one officially endangered species in the basin (S. brasiliensis), restricted range species (21.7\% of total species) should be considered in conservation efforts.
\end{abstract}

Keywords: ichthyofauna, biodiversity, survey, neotropical, Rio Grande do Sul.

\section{Peixes da bacia do rio Taquari-Antas (sistema da Laguna dos Patos), sul do Brasil}

\section{Resumo}

Os ambientes aquáticos da Bacia do rio Taquari-Antas (Bacia da Laguna dos Patos, sul do Brasil) vêm sofrendo considerável transformação, principalmente em razão da implantação de barragens para geração de energia elétrica. Com o objetivo de estabelecer um diagnóstico amplo da ictiofauna da Bacia do Taquari-Antas, realizou-se um inventário das espécies dessa bacia a partir de dados primários e secundários. Foram obtidos 5.299 registros válidos de espécies de peixe na bacia, representando 119 espécies e 519 localidades amostradas. Ocorrem, na bacia, 13 espécies não nativas, seis das quais são oriundas de outras bacias neotropicais. Cerca de $24 \%$ de todas as espécies carecem de descrição taxonômica no nível específico. Foram registradas três espécies nativas migradoras de longa distância (Leporinus obtusidens, Prochilodus lineatus e Salminus brasiliensis) e duas potenciais migradoras de média distância (Parapimelodus nigribarbis e Pimelodus pintado). O fato de uma espécie ser oficialmente reconhecida como ameaçada na bacia (S. brasiliensis) e a grande proporção de espécies de distribuição restrita (21,7\% do total) devem ser levados em consideração nos esforços de conservação.

Palavras-chave: ictiofauna, biodiversidade, inventário, neotropical, Rio Grande do Sul.

\section{Introduction}

The Brazilian freshwater fish fauna is extremely diverse, with more than 2,500 valid species distributed through several habitat types and river systems, and there is a growing number of new species being described (Buckup et al., 2007). However, river basins in Brazil are becoming increasingly transformed by human activities, particularly

in the southeastern and southern regions, where land use change, pollution and damming for hydroelectricity are the main factors affecting fish conservation (Agostinho et al., 2008; Barletta et al., 2010). This continuous process of environmental change threatens the existence of fish species and their habitats, therefore conservation planning and 
prioritization require information on species composition and distribution in relatively large areas. In Brazil, surveys for improving the knowledge base on freshwater fishes are frequently called for (Vari and Malabarba, 1998; Agostinho et al., 2005, 2008; Buckup et al., 2007).

In this paper, we present the results of a fish species survey in the Taquari-Antas river basin $\left(26.470 \mathrm{~km}^{2}\right)$, in southern Brazil. This region has been historically affected by urban, industrial and agricultural activities, although there are several relatively less affected areas of Atlantic forest and natural grasslands. In the early 2000s, river damming for hydropower generation became an additional cause of environmental transformation. By the end of 2010, there were 26 hydroelectric power plants (from $<1$ MW to 130 $\mathrm{MW}$ ) in operation or under construction in the TaquariAntas basin, with more than 80 sites under examination for potentially new dams (data from the Rio Grande do Sul State Foundation for Environment Protection - FEPAM, and from the Brazilian electric power authority database, ANEEL/SIGEL). In the lower Taquari river there is also a canal lock for navigation, which can be considered the first obstacle for upstream fish migration.

In spite of a relatively large number of recent taxonomic studies and fish sampling across the Taquari-Antas basin, a consolidated overview of the fish species composition and distribution is lacking. Studies providing a wider perspective of the Taquari-Antas fishes were only recently published (Malabarba et al., 2009; Luz-Agostinho et al., 2010), however their scope was limited to specific regions within the watershed. Malabarba et al. (2009) surveyed the fishes from the high basaltic plateau, including the headwaters of the Taquari-Antas and Caí rivers (both in the Patos Lagoon basin) and of Pelotas and Canoas rivers (upper Uruguay river basin). They found 46 species and a high degree of endemism for fishes of the Jacuí headwaters $(21.7 \%)$, which include the Taquari-Antas headwaters. Luz-Agostinho et al. (2010) found 70 species in the midstretch of the Taquari-Antas and several tributaries, and also report baseline information on the reproduction and feeding of several species.

Our main objective is to present a comprehensive survey of the fish species of the Taquari-Antas basin. We used primary data from our own field collections, but also compiled a large amount of secondary data, including samples from several different habitats. In particular, we aimed at producing a species list that is the best approximation of the actual species composition in the studied area, and where taxonomic consistence and uncertainties are objectively pointed out. We also assessed the fish fauna in terms of non-native species, conservation status, general spatial distribution patterns, species with restricted geographical distribution, and migratory species.

\section{Material and Methods}

\subsection{Study area}

The Taquari-Antas basin is situated in southern Brazil (state of Rio Grande do Sul) and is one of the main subbasins of the Patos Lagoon basin (Figure 1), which is a large drainage flowing into the Atlantic Ocean and is one of the freshwater ecoregions recognized by Abell et al. (2008). It is a $7^{\text {th }}$ order river basin (Strahler, 1957; stream network map at 1:250.000 scale) with a total area of $26.470 \mathrm{~km}^{2}$. The Antas river, as the main river is called in the upper section of the basin, flows from a high basaltic plateau (ca. 800 to $1200 \mathrm{~m}$ a.s.l) through deeply incised valleys until the lowlands, where it is known as Taquari river.

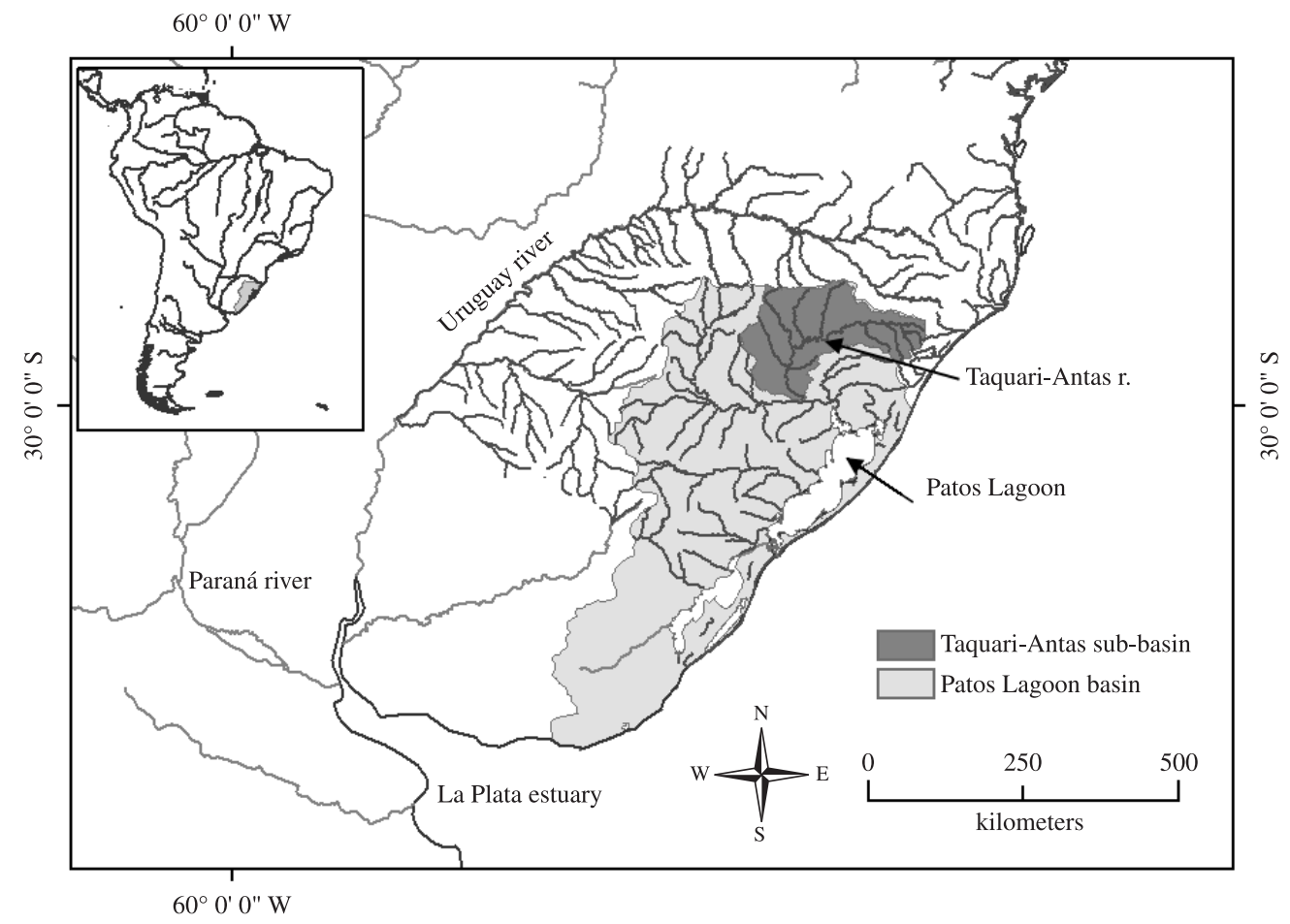

Figure 1. Geographic location of the Taquari-Antas basin within the Patos Lagoon basin. 
The lowlands flow through terrains formed by alluvial deposits in elevations between $20 \mathrm{~m}$ to $100 \mathrm{~m}$ a.s.l. The main river channel, from headwaters to the confluence with Jacuí river, is $c a .400 \mathrm{~km}$ long and the mean annual flow is $606 \mathrm{~m}^{3} \cdot \mathrm{s}^{-1}$ (Rio Grande do Sul, 2007).

\subsection{Species records}

We determined the fish species of the Taquari-Antas basin from primary and secondary data. Primary data were obtained by sampling fish assemblages at several localities across the study area during 2010. Secondary data were obtained by reviewing and validating records from the largest and most regionally representative fish collections (Museu de Ciências Naturais da Fundação Zoobotânica do Rio Grande do Sul, MCN; Museu de Ciências e Tecnologia da Pontifícia Universidade Católica do Rio Grande do Sul, MCP; Department of Zoology of Universidade Federal do Rio Grande do Sul, UFRGS). Additionally, we reviewed species records from scientific publications and technical environmental reports available at FEPAM.

The fish records compiled comprise samples obtained by several different fishing techniques (gill nets, seine nets, cast nets, dip nets and electrofishing) and encompassed several habitat types (small streams to large rivers, reservoirs and small wetlands).

\subsection{Geographical coordinates of species records}

After compiling the fish record database for the whole Taquari-Antas basin, we found three types of geographic location data: (a) descriptions of the sampling site geographic location without geographic coordinates (found mostly in museum records and in bibliographic sources), (b) geographic coordinates that had been obtained in the field, using GPS receivers and (c) geographic coordinates from unknown sources. In the first case, we approximated geographic coordinates on the basis of the site descriptions or site locations pictured in maps included in the bibliographic sources, using a geographic information system ArcGis (ESRI) and the digital version of the official 1:50.000 cartographic database of Rio Grande do Sul (Hasenack and Weber, 2010). This cartographic database includes the stream network, roads, cities and detailed toponymy, and is usually used by researchers for field navigation and for describing sampling site locations. Information about the datum associated with geographic coordinates was rare in the database, therefore we assumed WGS84 for all records.

\subsection{Taxonomic validation}

Fish samples collected by the authors were identified or validated by taxonomy specialists. Voucher specimens of all species can be found in at least one of the reviewed museum collections (MCN, MCP, UFRGS). Species records from secondary sources (museum databases and non-taxonomic bibliographic sources) have been subject to nomenclature actualization (e.g., Astyanax alburnus to Cyanocharax alburnus, $c f$. Malabarba and Weitzman, 2003; Pimelodus maculatus to Pimelodus pintado, $c f$. Azpelicueta et al., 2008). Museum specimens were examined only when the actual presence of a species in the Taquari-Antas basin depended exclusively on the valid identification of a particular sample. We did not consider as valid any record with dubious taxonomic identification and that could not be validated by examining vouchers specimens in scientific collections. We also excluded any record with a geographic location that could not be unequivocally determined to be within the Taquari-Antas basin. The taxonomic classification follows Reis et al. (2003a), except for the use of Labriformes (Wiley and Johnson, 2010).

We assessed the species conservation status according to the endangered species list of Rio Grande do Sul (Reis et al., 2003b) and the Brazilian list of endangered fish species (Instrução Normativa do Ministério do Meio Ambiente $\mathrm{n}^{\circ}$ 05, 21 de maio de 2004). To determine species with restricted geographical ranges $\left(<10.000 \mathrm{~km}^{2}\right.$ sensu Nogueira et al., 2010), we used data from our survey and primary literature, rather than assuming a priori only the species listed by Nogueira et al. (2010). We considered as migratory those species mentioned by Luz-Agostinho et al. (2010). Any species whose natural distribution does not include the Patos Lagoon basin was considered as nonnative. We also described the general distribution pattern of species across the main geomorphological sections of the Taquari-Antas basin (Lowlands, Mid-slopes, and Plateau). Species were classified as typical of a section when $>70 \%$ of their records were included in only one section. Species occurring in all sections and with more than $30 \%$ records in at least two sections were considered to be well distributed across the Taquari-Antas basin.

\section{Results}

We obtained 5,299 valid presence records of fish species in the Taquari-Antas basin, representing 119 species (including non-native species; Table 1) and 519 sampling sites (Figure 2). The total number of species (119) was determined only after a validation process on a preliminary listing of 266 nominal taxa obtained from the secondary data. Most sampling sites (43.3\%) were located in higher elevation areas of the plateau, while the remaining were situated in the slopes between the lowlands and the plateau $(32 \%)$ and in the lowlands $(24.7 \%)$ (Figure 2).

There were records for 13 non-native species (10.9\% of the total number of species), six of which are native to other Neotropical river basins (Table 2). About 25\% of the total native species are still lacking a taxonomic description at the species level. Several of the recorded species have a relatively limited geographical distribution (Table 2), including only the Taquari-Antas basin, or the Taquari-Antas and adjacent neighboring watersheds (Upper Uruguay, Sinos, and Caí river, and the headwaters of small coastal watersheds). Only Salminus brasiliensis is officially listed as a threatened species (Reis et al., 2003b).

At least six migratory species were recorded in the Taquari-Antas basin: the long distance migrants Leporinus obtusidens, Prochilodus lineatus, Salminus brasiliensis, the mid-distance migrants Parapimelodus nigribarbis and Pimelodus pintado, and the non-native Acestrorhynchus pantaneiro. The migratory species were represented by few locality records (except for Pimelodus pintado, Figure 3), and were mostly limited to the mid- and lower sections of the rivers, downstream the Cachoeirão rapids, except for one record of Leporinus obtusidens at the Tainhas river (see Figure 3). Pimelodus pintado was the most widely distributed migratory species with several records upstream the Cachoeirão and in upper parts of the main tributaries of the Antas river (Prata, Carreiro and Guaporé rivers). 
Table 1. Fish species of the Taquari-Antas river basin (Patos Lagoon basin), southern Brazil.

\begin{tabular}{|c|c|c|}
\hline Taxon & Origin & Comments \\
\hline \multicolumn{3}{|l|}{ ATHERINIFORMES } \\
\hline \multicolumn{3}{|l|}{ Atherinopsidae } \\
\hline Odontesthes humensis & Native & \\
\hline Odontesthes sp. & Native & \\
\hline \multicolumn{3}{|l|}{ CHARACIFORMES } \\
\hline \multicolumn{3}{|l|}{ Anostomidae } \\
\hline Leporinus obtusidens & Native & \\
\hline Schizodon jacuiensis & Native & \\
\hline \multicolumn{3}{|l|}{ Acestrorhynchidae } \\
\hline Acestrorhynchus pantaneiro & Non-native & $\begin{array}{l}\text { This species is native to the Paraná-Paraguay (Menezes, 2007). It is } \\
\text { presently found as a non-native species in the Patos Lagoon basin (see } \\
\text { Saccol and Pereira et al., 2006). }\end{array}$ \\
\hline \multicolumn{3}{|l|}{ Characidae } \\
\hline Aphyocharax anisitsi & Non-native & $\begin{array}{l}\text { This species is native to the Paraná-Paraguay (Souza-Lima, 2007). } \\
\text { Presently it is found as a non-native species in the Patos Lagoon basin. }\end{array}$ \\
\hline Astyanax sp. aff. fasciatus & Native & Nomenclature follows Melo and Buckup (2006) \\
\hline Astyanax brachypterygium & Native & $\begin{array}{l}\text { Restricted to headwater streams in high elevation ( }>1000 \mathrm{~m} \text { ). It is not } \\
\text { exclusive from the Taquari-Antas basin (Bertaco and Malabarba, 2001) }\end{array}$ \\
\hline Astyanax cremnobates & Native & $\begin{array}{l}\text { Restricted to headwater streams in high elevation (>1000 m). It is not } \\
\text { endemic to the Taquari-Antas basin (Bertaco and Malabarba, 2001) }\end{array}$ \\
\hline Astyanax eigenmanniorum & Native & \\
\hline Astyanax henseli & Native & \\
\hline Astyanax jacuhiensis & Native & \\
\hline Astyanax laticeps & Native & \\
\hline Astyanax obscurus & Native & \\
\hline Astyanax sp. 1 & Native & $\begin{array}{l}\text { Undescribed species found across the Jacuí river basin (Upper Patos } \\
\text { Lagoon basin) (V. A. Bertaco) }\end{array}$ \\
\hline Astyanax sp. 2 & Native & $\begin{array}{l}\text { Undescribed species found across found across the Jacuí, Uruguay e } \\
\text { Tramandaí river basins (V. A. Bertaco) }\end{array}$ \\
\hline Astyanax sp.3 & Native & $\begin{array}{l}\text { Undescribed species found only in the higher tributaries of the Taquari- } \\
\text { Antas basin (V. A. Bertaco) }\end{array}$ \\
\hline Astyanax sp.4 & Native & $\begin{array}{l}\text { Undescribed species found only in the Carreiro river and its tributaries } \\
\text { (Taquari-Antas basin) (V. A. Bertaco). }\end{array}$ \\
\hline Bryconamericus ecai & Native & $\begin{array}{l}\text { This species is known only from its type locality and is endemic to the } \\
\text { Taquari-Antas basin (Silva, 2004) }\end{array}$ \\
\hline Bryconamericus iheringii & Native & \\
\hline Bryconamericus patriciae & Native & \\
\hline Charax stenopterus & Native & \\
\hline Cheirodon ibicuhiensis & Native & \\
\hline Cheirodon interruptus & Native & \\
\hline Cyanocharax alburnus & Native & \\
\hline $\begin{array}{l}\text { Cyanocharax } \\
\text { dicropotamicus }\end{array}$ & Native & \\
\hline Diapoma speculiferum & Native & \\
\hline Diapoma thauma & Native & $\begin{array}{l}\text { Known only from the Taquari-Antas and Sinos river basins (Menezes } \\
\text { and Ribeiro, 2010) }\end{array}$ \\
\hline Heterocheirodon jacuiensis & Native & \\
\hline Hyphessobrycon igneus & Native & $\begin{array}{l}\text { This species was usually identified as } H \text {. bifasciatus, which does not } \\
\text { occur in the Patos Lagoon basin (F. L. Barros, personal communication } \\
\text { to C.A.S. Lucena; Carvalho, 2011) }\end{array}$ \\
\hline Hyphessobrycon luetkenii & Native & \\
\hline Hypobrycon sp. & Native & New species under description by L. R. Malabarba and J. Pezzi da Silva \\
\hline
\end{tabular}


Table 1. Continued...

\begin{tabular}{|c|c|c|}
\hline Taxon & Origin & Comments \\
\hline Oligosarcus jacuiensis & Native & \\
\hline Oligosarcus jenynsii & Native & \\
\hline Oligosarcus robustus & Native & \\
\hline Oligosarcus sp. & Native & $\begin{array}{l}\text { Potentially a new species (N. A. Menezes, personal communication to } \\
\text { C. A. S. Lucena). We found one record for O. brevioris (MCP18700), } \\
\text { however the data on the collection site is ambiguous and insufficient to } \\
\text { validate the occurrence of this species in the Taquari-Antas basin }\end{array}$ \\
\hline Pseudocorynopoma doriae & Native & \\
\hline Salminus brasiliensis & Native & \\
\hline Serrapinnus calliurus & Native & \\
\hline \multicolumn{3}{|l|}{ Crenuchidae } \\
\hline Characidium gr. zebra & Native & \\
\hline Characidium orientale & Native & \\
\hline Characidium pterostictum & Native & \\
\hline Characidium tепие & Native & \\
\hline \multicolumn{3}{|l|}{ Curimatidae } \\
\hline Cyphocharax spilotus & Non-native & $\begin{array}{l}\text { This species was known only for the Uruguay river and lower Paraná } \\
\text { basin, however it has been recently found also in the Patos Lagoon basin } \\
\text { (e.g., Flores-Lopes et al., 2010; Luz-Agostinho et al., 2010) }\end{array}$ \\
\hline Cyphocharax voga & Native & \\
\hline Steindachnerina biornata & Native & \\
\hline \multicolumn{3}{|l|}{ Erythrinidae } \\
\hline Hoplias lacerdae & Non-native & $\begin{array}{l}\text { Its original distribution includes the Ribeira do Iguape and Uruguay } \\
\text { river basins (Oyakawa and Mattox, 2009). Its introduction in the Patos } \\
\text { Lagoon basin has possibly resulted from escapement from small fishing } \\
\text { ponds and fish culture facilities }\end{array}$ \\
\hline Hoplias aff. malabaricus & Native & \\
\hline \multicolumn{3}{|l|}{ Prochilodontidae } \\
\hline Prochilodus lineatus & Native & \\
\hline \multicolumn{3}{|l|}{ CLUPEIFORMES } \\
\hline \multicolumn{3}{|l|}{ Clupeidae } \\
\hline Platanichthys platana & Native & \\
\hline \multicolumn{3}{|l|}{ Engraulididae } \\
\hline Lycengraulis grossidens & Native & \\
\hline \multicolumn{3}{|l|}{ CYPRINIFORMES } \\
\hline \multicolumn{3}{|l|}{ Cyprinidae } \\
\hline Ctenopharingodon idella & Non-native & Native from Asia, this species has been introduced for aquaculture activities \\
\hline Cyprinus carpio & Non-native & Native from Asia, this species has been introduced for aquaculture activities \\
\hline Hypophthalmichthys nobilis & Non-native & $\begin{array}{l}\text { Native from Asia, this species has been introduced mainly for } \\
\text { aquaculture activities }\end{array}$ \\
\hline \multicolumn{2}{|l|}{ Anablepidae } & \\
\hline Jenynsia eirmostigma & Native & $\begin{array}{l}\text { Endemic to high elevation streams in the Basaltic Plateau where the headwa- } \\
\text { ters of the Antas and Upper Uruguay rivers are situated (Malabarba et al., 2009) }\end{array}$ \\
\hline \multicolumn{3}{|l|}{ Poecilidae } \\
\hline Cnesterodon brevirostratus & Native & $\begin{array}{l}\text { Restricted to small streams and wetlands in high elevation areas; it is } \\
\text { not endemic to the Taquari-Antas basin (Malabarba et al., 2009) }\end{array}$ \\
\hline Cnesterodon sp. & Native & $\begin{array}{l}\text { Undescribed species. Occurs in small streams at high elevation areas; } \\
\text { probably not endemic to the Taquari-Antas basin (Malabarba et al., 2009) }\end{array}$ \\
\hline Phalloceros caudimaculatus & Native & \\
\hline
\end{tabular}


Table 1. Continued...

\begin{tabular}{ccc}
\hline Taxon & Origin & Comments \\
\hline
\end{tabular}

\section{GYMNOTIFORMES}

Gymnotidae

Gymnotus aff. carapo

Gymnotus chimarrao

Sternopygidae

Eigenmannia trilineata

\section{LABRIFORMES}

\section{Cichlidae}

Australoheros sp.

Australoheros taura

Crenicichla lepidota

Crenicichla punctata

Geophagus brasiliensis

Gymnogeophagus gymnogenys

Gymnogeophagus labiatus

Oreochromis niloticus

\section{PERCIFORMES}

\section{Centrarchidae}

Micropterus salmoides

\section{Sciaenidae}

Pachyurus bonariensis

\section{SALMONIFORMES}

\section{Salmonidae}

Onchorynchus mykiss

\section{SILURIFORMES}

\section{Aspredinidae}

Bunocephalus erondinae

Pseudobunocephalus

iheringii

\section{Auchenipteridae}

Glanidium sp.

Trachelyopterus lucenai

\section{Callichthyidae}

$\begin{array}{ll}\text { Corydoras paleatus } & \text { Native } \\ \text { Hoplosternum littorale } & \text { Native } \\ \text { Heptapteridae } & \\ \text { Heptapterus mustelinus } & \text { Native } \\ \text { Heptapterus sp. } & \text { Native } \\ \text { Pimelodella australis } & \text { Native } \\ \text { Rhamdella eriarcha } & \text { Native }\end{array}$

Native

Native

Native

Native

Native

Native

Native

Native

Native

Native

Native

Native

Native Albert and Crampton (2003) restricted the distribution of Gymnotus carapo to the Amazon and Orinoco basins, coastal rivers of the Guianas and the Parnaíba and Itapicuru rivers in northeastern Brazil. There are undescribed species in the Patos Lagoon basin, including the one in the Taquari-Antas basin. It is possibly a new species in the $G$. carapo group

Non-native Introduced for aquaculture, it has escaped or sometimes intentionally released in natural waters

Non-native Native to North America, this species was intentionally introduced in the 1980s for sport fishing in fish ponds and streams (Malabarba et al., 2009)

Non-native This species is native to the Paraná-Paraguay (Casatti, 2003). It is presently found as a non-native species in the Patos Lagoon basin (see Dufech and Filaho, 2007).

Non-native Native to North America, this species was intentionally introduced in the 1980s for sport fishing in high elevation streams (Malabarba et al., 2009)

Comparative studies of the lower Jacuí populations are needed to determine whether this is a new species. Geographically, the closer species is G. catharinensis Miranda-Ribeiro, from Tubarão river, in the state Santa Catarina, southern Brazil

Non-native Its original distribution includes the Uruguay river and Patos Lagoon basins. This species was not mentioned in Akama and Sarmento-Soares (2007) because it was considered a synonym of Parauchenipterus porosus (Eigenmann and Eigenmann, 1888) in Akama (2004). 
Table 1. Continued...

\begin{tabular}{|c|c|c|}
\hline Taxon & Origin & Comments \\
\hline Rhamdia quelen & Native & $\begin{array}{l}\text { We keep the use of Rhamdia quelen until conclusive studies about the } \\
\text { populations of this genus are available }\end{array}$ \\
\hline \multicolumn{3}{|l|}{ Ictaluridae } \\
\hline Ictalurus punctatus & Non-native & $\begin{array}{l}\text { This north-american catfish was introduced in fish ponds for fish } \\
\text { production and escaped into natural waters }\end{array}$ \\
\hline \multicolumn{3}{|l|}{ Loricariidae } \\
\hline Ancistrus brevipinnis & Native & \\
\hline Ancistrus sp. & Native & \\
\hline Eurycheilichthys sp. 1 & Native & $\begin{array}{l}\text { Undescribed species, with distribution restricted to the Taquari-Antas basin; it } \\
\text { is known only from the Fão river (R. E. Reis, personal communication) }\end{array}$ \\
\hline Eurycheilichthys sp. 2 & Native & $\begin{array}{l}\text { Undescribed species, potentially endemic to the Taquari-Antas basin } \\
\text { (see Reis and Carvalho, 2007) }\end{array}$ \\
\hline Eurycheilichthys sp. 3 & Native & $\begin{array}{l}\text { Undescribed species, with geographical distribution restricted to the } \\
\text { Taquari-Antas basin; it is known only from the Prata river (R. E. Reis, } \\
\text { personal communication) }\end{array}$ \\
\hline Eurycheilichthys sp. 4 & Native & $\begin{array}{l}\text { Undescribed species, with geographical distribution restricted to the } \\
\text { Taquari-Antas basin; it is known only from the upper Guaporé river } \\
\text { (R.E. Reis, personal communication) }\end{array}$ \\
\hline Eurycheilichthys sp. 5 & Native & $\begin{array}{l}\text { Undescribed species, potentially endemic to the Taquari-Antas basin } \\
\text { (see Reis and Carvalho, 2007) }\end{array}$ \\
\hline Eurycheilichthys sp. 6 & Native & $\begin{array}{l}\text { Undescribed species, potentially endemic to the Taquari-Antas basin } \\
\text { (see Reis and Carvalho, 2007) }\end{array}$ \\
\hline Eurycheilichthys sp. 7 & Native & $\begin{array}{l}\text { Undescribed species, potentially endemic to the Taquari-Antas basin } \\
\text { (see Reis and Carvalho, 2007) }\end{array}$ \\
\hline Hemiancistrus punctulatus & Native & \\
\hline Hisonotus armatus & Native & \\
\hline Hisonotus carreiro & Native & Endemic to the Taquari-Antas basin (Carvalho and Reis, 2011) \\
\hline Hisonotus prata & Native & Endemic to the Taquari-Antas basin (Carvalho and Reis, 2011) \\
\hline Hisonotus vireo & Native & \\
\hline Hypostomus aspilogaster & Native & \\
\hline Hypostomus commersonii & Native & \\
\hline Loricariichthys anus & Native & \\
\hline Pareiorhaphis hystrix & Native & \\
\hline Rineloricaria baliola & Native & \\
\hline Rineloricaria cadeae & Native & \\
\hline Rineloricaria malabarbai & Native & \\
\hline $\begin{array}{l}\text { Rineloricaria } \\
\text { microlepidogaster }\end{array}$ & Native & \\
\hline Rineloricaria strigilata & Native & \\
\hline \multicolumn{3}{|l|}{ Pimelodidae } \\
\hline Parapimelodus nigribarbis & Native & \\
\hline Pimelodus pintado & Native & \\
\hline \multicolumn{3}{|l|}{ Pseudopimelodidae } \\
\hline Microglanis cottoides & Native & \\
\hline \multicolumn{3}{|l|}{ Trichomycteridae } \\
\hline Homodiaetus anisitsi & Native & \\
\hline Ituglanis sp. & Native & First record of this genus in the Patos Lagoon basin (J. Ferrer) \\
\hline Scleronema sp. & Native & $\begin{array}{l}\text { Scleronema sp. is known only from two records in the Taquari-Antas } \\
\text { basin; it is different from other species known in Rio Grande do Sul }\end{array}$ \\
\hline Trichomycterus sp. 1 & Native & $\begin{array}{l}\text { Undescribed species, potentially endemic to the Taquari-Antas basin; } \\
\text { known only from the Turvo and Prata sub-basins (J. Ferrer) }\end{array}$ \\
\hline Trichomycterus sp.2 & Native & Undescribed species (J. Ferrer) \\
\hline Trichomycterus sp.3 & Native & Undescribed species (J. Ferrer) \\
\hline
\end{tabular}


Table 1. Continued...

\begin{tabular}{lll}
\hline \multicolumn{1}{c}{ Taxon } & Origin & \multicolumn{1}{c}{ Comments } \\
\hline Trichomycterus sp.4 & Native & Undescribed species (J. Ferrer) \\
Trichomycterus tropeiro & Native & $\begin{array}{l}\text { Endemic to the headwaters of the Taquari-Antas basin (Ferrer and } \\
\text { Malabarba, 2011), it occurs only in elevations }>1000 \mathrm{~m}\end{array}$ \\
SYNBRANCHIFORMES & & \\
$\begin{array}{l}\text { Synbranchidae } \\
\text { Synbranchus marmoratus }\end{array}$ & Native & \\
\hline
\end{tabular}

Table 2. Proportion of non-native species and proportion of restricted range species occurring in the Taquari-Antas basin. Restricted range species have total geographical distribution of less than $10.000 \mathrm{~km}^{2}$ (sensu Nogueira et al., 2010).

\begin{tabular}{lcc}
\hline \multicolumn{1}{c}{ Non-native species (geographic origin) } & n & \% total species \\
\hline Neotropical (South America) & 6 & 5.1 \\
Other regions (Asia, North America, Africa) & 7 & 5.9 \\
Total $\quad$ Restricted range species & 13 & 10.9 \\
\cline { 2 - 2 } & n & \% (total native species) \\
Distribution in the Taquari-Antas and adjacent river basins & 7 & 6.6 \\
Endemic or potentially endemic to the Taquari Antas basin ${ }^{1}$ & 16 & 15.1 \\
Total (restricted distribution) & 23 & 21.7 \\
\hline
\end{tabular}

${ }^{1}$ Distribution status of undescribed species needs confirmation from further studies.

The fish fauna of the Taquari-Antas presents a relatively clear distribution pattern across the three geomorphological sections of the basin (Figure 4). Most species (58\%) are typically distributed in lowland rivers and streams, but about half of these species had at least a few records ( $<30 \%$ of total specific records) in the Mid-slope valleys and in the Plateau. A typical fish fauna is also found in the Plateau ( $20 \%$ of total native species), including 16 species for which all records were located in this geomorphological section. In the transition between the Plateau and the Lowlands - i.e., the Mid-slopes section - there is an overlap in the distribution of lowland species and headwater species, with few typical species ( $9.5 \%$ of total species). Only $12.4 \%$ of all native species were relatively common in the three geomorphological sections (e.g., Bryconamericus iheringii, Characidium pterostictum, Geophagus brasiliensis, Gymnotus aff. carapo, Hyphessobrycon luetkenii, Phalloceros caudimaculatus).

\section{Discussion}

According to our survey, knowledge about the fishes of the Taquari-Antas basin was relatively poor until the late 1990s, and consisted of several records in museum databases (the oldest record in the examined collections dates from $1977 ; 62 \%$ of the collection records were sampled after 1999), and descriptions of species with geographical distributions that included the region (e.g., Malabarba, 1989; Buckup, 1993; Malabarba and Mahler Junior, 1998; Cardoso and Malabarba, 1999). In the late 1990 s, fish sampling was intensified as part of baseline studies for environmental impact assessments (EIA), which are demanded by the State and Federal environmental agencies (FEPAM and IBAMA) in Brazil. Vouchers of most of these samples are now kept in the fish collections of the MCN, MCP and UFRGS. From 2000 to 2011, several new species occurring in the basin were described (e.g, Silva, 2004; Rodriguez and Reis, 2008; Carvalho et al., 2008; Carvalho and Reis, 2009; Cognato et al., 2009; Ottoni and Cheffe, 2009; Menezes and Ribeiro, 2010; Ferrer and Malabarba, 2011; Menezes and Weitzman, 2011), but there are few studies and publications on ecology, reproductive biology or conservation (Guadagnin et al., 1998; Majolo, 2005; Alves and Fontoura, 2009; Hirschmann et al., 2008; Luz-Agostinho et al., 2010).

The number of species in the Taquari-Antas basin represents $c a$. $65 \%$ of the total number of known species for the Patos Lagoon basin (160 species, including 35 undescribed species; Malabarba et al., 2009). The number of native species in physiographically similar and geographically close river basins varies from 51 (Pardinho river, Patos Lagoon basin; Ribeiro and Köhler, 2007) to 79 (Maquiné river, in the Tramandaí river system; F. G. Becker, unpublished data) and 89 (Sinos river, Patos Lagoon basin; Leal et al., 2009). However, a proper comparison is not possible because these studies used distinct survey methods and because the studied watersheds vary in total area and ecological integrity.

The proportion of undescribed species in the TaquariAntas is relatively large (23.6\%) and similar to estimates for the whole Patos Lagoon and Uruguay river basins (21.9\% and $22.2 \%$, respectively; Malabarba et al., 2009). It is particularly important to note that part of these undescribed species are small headwater fish (e.g. Eurycheilichthys and Trichomycterus), with potentially small geographic ranges, reinforcing the previous observations of a highly underestimated diversity in the region (Malabarba et al., 2009). As noted by Ferrer and Malabarba (2011), all the highly endemic species described to the basaltic highlands (which include the Taquari-Antas mid-slope rivers and 


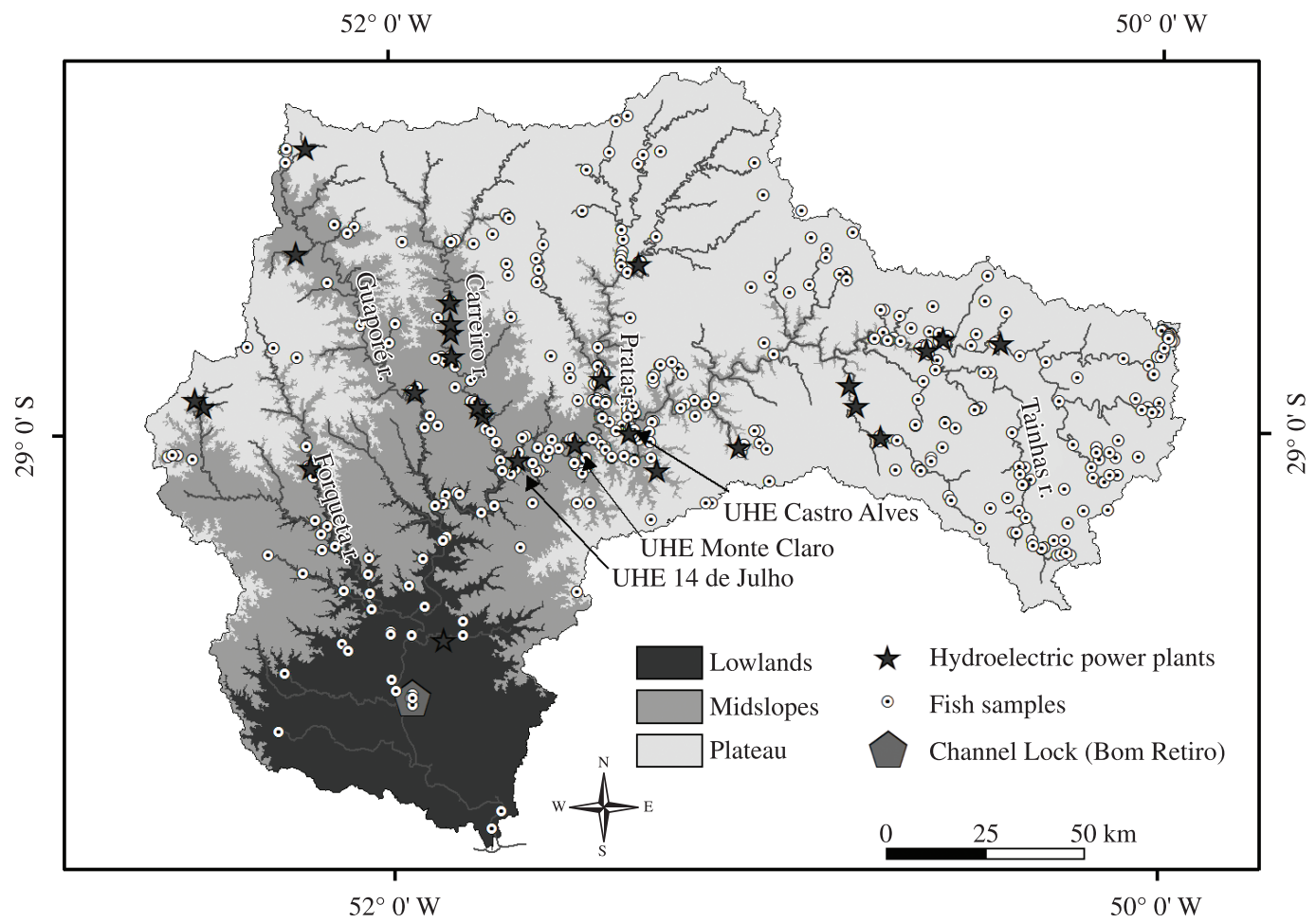

Figure 2. Locations of fish sample sites ( $n=519$; circles may represent more than one site) in the Taquari-Antas basin, and position of the hydroelectric power plants (>0.5 MW) in operation or in different construction stages in early 2011 (black squares). Arrows indicate the three main dams in the basin (UHE = hydroelectric power plant).

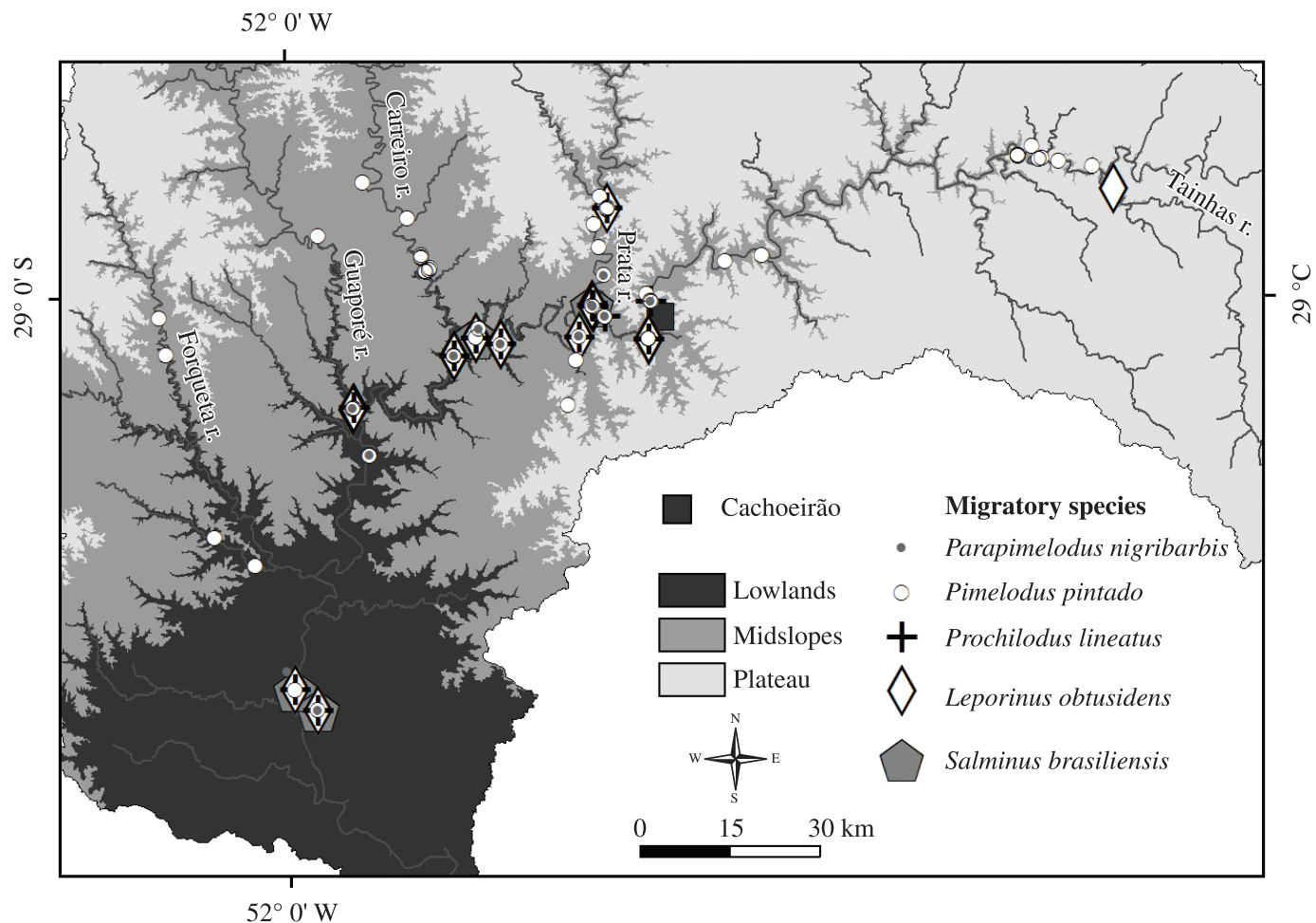

Figure 3. Records of migratory species in the Taquari-Antas basin. The Cachoeirão is a short stretch of the main channel of the Antas river with strong rapids and used to be considered a possible obstacle to several species. It is presently situated between the Castro Alves and Monte Claro dams. 
headwater streams) have been discovered and described in the last 20 years. It is also interesting that some undescribed species of Astyanax are widely distributed across adjacent river basins, but at least two are potentially endemic to areas within the Taquari-Antas basin.

The main distribution of the migratory species in the Antas river seems to be limited upstream by the strong rapids known as "Cachoeirão", as previously noted by Luz-Agostinho et al. (2010). However, these species were represented by few records in our survey (except for $P$. pintado) and were not effectively sampled before the construction of the main dams in the Antas river (14 de Julho, Monte Claro and Castro Alves, in the early 2000s; Figure 3). The "dourado", Salminus brasiliensis, probably used to be present in upper reaches of the basin, as suggested by occurrence data determined by Alves and Fontoura (2009) from interviews with fishermen. The migratory status of Pimelodus pintado is still not well established (Alves and Fontoura, 2009), but its reproductive behavior could be similar to Pimelodus maculatus. The latter species migrates for long-distances, but is abundant in serially impounded rivers, as the Tietê and Grande rivers (Agostinho et al., 2007), probably being able to reproduce in shorter free river stretches (Agostinho et al., 2003).

We registered a high proportion of species with small geographical ranges $\left(\mathrm{ca} .10000 \mathrm{~km}^{2}\right.$ in range, following Nogueira et al., 2010), either endemic to the Taquari-Antas basin or not (Table 2). These numbers were based on recent publications (see Table 1) and on-going taxonomic investigations (J. Ferrer; V. A. Bertaco; R. E. Reis), and add another 11 species to those already listed by Nogueira et al. (2010). Most of these species occur in the upper portions of the basin (only in the Plateau or also in the Mid-slopes and valleys), as Eurycheilichthys spp. and Trichomycterus spp.. At least one species is known only from its type locality (Bryconamericus ecai, Silva, 2004) despite the extensive sampling in the basin. Because restricted range species are potentially more susceptible to environmental impacts and to extinction, they should be considered as targets for assessments in conservation planning and environmental licensing. This is particularly relevant in the Taquari-

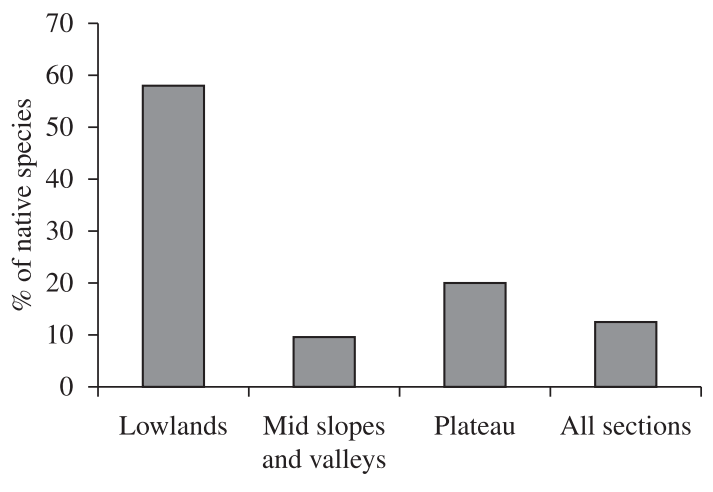

Geomorphological section

Figure 4. Percent distribution of native fish species $(n=105)$ in the main geomorphological sections of the Taquari-Antas basin. In All sections, we included species occurring in the three geomorphological sections and with more than $30 \%$ records in at least two of them.
Antas basin, in face of the high potential for increase in the number of dams for hydroelectric power production and for land transformation (forestry and agriculture) in the upper sections of the basin.

The non-native species represented a relevant proportion $(10.9 \%)$ of the total species registered in the basin, however information on their abundance, population dynamics and on their impacts on the native biota is still lacking. About half of the non-native species are original from non-Neotropical regions; some of these were introduced in fish ponds for aquaculture production and escaped into natural habitats (e.g. Cyprinus carpio, Ictalurus punctatus and Oreochromis niloticus), while others were released directly into streams and rivers for sport fishing (the black bass, Micropterus salmoides, and the rainbow trout, Onchorynchus mykiss, particularly in streams of the basaltic plateau). Results from a fish monitoring program with extensive sampling between 2002-2009 indicated that non-native species occur only in low abundances in the mid-lower Taquari-Antas, and evidence for reproductive populations has been indirectly suggested only for C. carpio (Luz-Agostinho et al., 2010). Some of the Neotropical non-natives were probably unintentionally introduced via inter-basin man-made connections resulting from land management for agriculture (rice fields), and eventually dispersed rapidly and reached high abundances in different parts of the Patos Lagoon basin (e.g. Pachyurus bonariensis and Trachelyopterus lucenai, see Becker, 2002; SaccolPereira et al., 2006; Becker et al., 2007; Dufech and Fialho, 2007). We found museum records (MCP) for Tilapia rendalli collected in fish ponds in the late 1970s, however there was no record of this species in natural waters at the Taquari-Antas basin.

Considering the results of the present inventory, conservation in the Taquari-Antas basin should consider at least the following three components of the fish fauna. One aspect is to protect habitat for migratory fish (including the endangered Salminus brasiliensis), which can only be accomplished if some rivers receive no more dams. An example is the Guaporé river, which seems to function as an alternative reproductive area after the damming of the Taquari-Antas river (Luz-Agostinho et al., 2010). A second point is the protection or restoration of streams and rivers containing restricted range and endemic species, which requires an effort for formal description of these species and their geographical ranges. The third point is taking action to prevent the escapement of non-native species from fish ponds or their deliberate in natural waters, particularly where restricted range and endemic species are present.

Acknowledgements - We would like to thank Marco A. Azevedo for providing access to the the MCN collection records and to Luiz Roberto Malabarba and João Paulo Miranda for providing access to the UFRGS fish collection database. Adriano Cunha (Biolaw) kindly provided information on several fish records from the studied region. Dolores Pineda and Sílvia Pagel provided access to data from the environmental database of FEPAM. Ana Luiza Matte and Bruna Arbo Meneses helped in data management and in checking the geographical coordinates of fish records. Collections made by F. G. Becker were made under authorization of the Instituto Brasileiro do Meio Ambiente e dos Recursos Naturais Renováveis (IBAMA; License n. 1870068). 


\section{References}

ABELL, R., THIEME, ML., REVENGA, C., BRYER, M., KOTTELAT, M., BOGUTSKAYA, N., COAD, B., MANDRAK, N., CONTRERAS-BALDERAS, S., BUSSING, W., STIASSNY, MLJ., SKELTON, P., ALLEN, GR., UNMACK, P., NASEKA, A., NG, R., SINDORF, N., ROBERTSON, J., ARMIJO, E., HIGGINS, JV., HEIBEL, TJ., WIKRAMANAYAKE, E., OLSON, D., LÓPEZ, HL., REIS, RE., LUNDBERG, JG., SABAJ-PÉREZ, MH. and PETRY, P., 2008. Freshwater Ecoregions of the World: A new map of biogeographic units for freshwater biodiversity conservation. BioScience, vol. 58, no. 5, p. 403-414. http://dx.doi. org/10.1641/B580507

AGOSTINHO, AA., GOMES, LC. and PELICICE, FM., 2008. Dams and fish fauna of the Neotropical region: impacts and management related to diversity and fisheries. Brazilian Journal of Biology, vol. 68, no. 4, p. 1119-1132. PMid:19197482. http:// dx.doi.org/10.1590/S1519-69842008000500019

-, 2007. Ecologia e Manejo dos Recursos Pesqueiros em Reservatórios do Brasil. Maringá: EDUEM. 501p.

AGOSTINHO, AA., GOMES, LC., SUZUKI, HI. and JÚLIO JUNIOR, HF., 2003. Migratory Fishes of the upper Paraná river basin, Brazil. In CAROLSFELD, J., HARVEY, B., ROSS, C. and BAER, A. Migratory fishes of South America: biology, fisheries and conservation status. Ottawa: World Fisheries Trust/World Bank/IDRC. 380 p.

AGOSTINHO, AA., THOMAZ, SM. and GOMES, LC., 2005 Conservation of the Biodiversity of Brazil's Inland Waters. Conservation Biology, vol.19, no. 3, p. 646-652. http://dx.doi. org/10.1111/j.1523-1739.2005.00701.x

AKAMA, A., 2004. Sistemática dos gêneros Parauchenipterus Bleeker, 1862 e Trachelyopterus Valenciennes, 1840 (Siluriformes, Auchenipteridae). São Paulo: Universidade de São Paulo. 375 p. Tese de doutorado.

AKAMA, A. and SARMENTO-SOARES, LM., 2007. Família Auchenipteridae. In BUCKUP, PA., MENEZES, NA. and GHAZZI, MS. (Eds.). Catálogo das espécies de peixes de água doce do Brasil. Rio de Janeiro: Museu Nacional. p. 116-120. Série Livros.

ALBERT, J. S. and CRAMPTON, WGR., 2003. Seven new species of the neotropical electric fish Gymnotus (Teleostei, Gymnotiformes) with a redescription of G. carapo (Linnaeus). Zootaxa, no. 287, p. 1-54

ALVES, TP. and FONTOURA, NF., 2009. Statistical distribution models for migratory fish in Jacuí basin, South Brazil. Neotropical Ichthyology, vol. 7, no. 4, p. 647-658. http://dx.doi.org/10.1590/ S1679-62252009000400014

AZPELICUETA, MM., LUNDBERG, JG. and LOUREIRO, M., 2008. Pimelodus pintado (Siluriformes: Pimelodidae), a new species of catfish from affluent rivers of Laguna Merín, Uruguay, South America. Proceedings of the Academy of Natural Sciences of Philadelphia, vol. 157, p. 149-162.

BARLETTA, M., JAUREGUIZAR, AJ., BAIGUN, C., FONTOURA, NF., AGOSTINHO, AA., ALMEIDA-VAL, VMF., VAL, AL., TORRES, RA., JIMENES-SEGURA, LF., GIARRIZZO, T., FABRÉ, NN., BATISTA, VS., LASSO, C., TAPHORN, DC., COSTA, MF., CHAVES, PT., VIEIRA, JP. and CORREAA, MFM., 2010. Fish and aquatic habitat conservation in South America: a continental overview with emphasis on neotropical systems. Journal of Fish Biology, vol. 76, p. 2118-2176. PMid:20557657. http://dx.doi. org/10.1111/j.1095-8649.2010.02684.x

BECKER, FG., 2002. Observations on the reproduction, sex ratio and size composition of Trachelyopterus lucenai (Teleostei: Auchenipteridae) in lake Guaíba, RS, Brazil. Biociências (Porto Alegre), vol. 9, no. 2, p. 85-96.
BECKER, FG., GROSSER, KM., MILANI, PC. and BRAUN, AS., 2007. Peixes. In BECKER, FG., MOURA, LA. and RAMOS, RA. (Org.). Biodiversidade: Regiões da Lagoa do Casamento e dos Butiazais de Tapes, Planície Costeira do Rio Grande do Sul. Brasília: Ministério do Meio Ambiente. p. 262-275.

BERTACO, VA. and MALABARBA, LR., 2001. Description of two new species of Astyanax (Teleostei: Characidae) from headwater streams of Southern Brazil, with comments on the A. scabripinnis species complex. Ichthyological Exploration of Freshwaters, vol. 12, no. 3, p. 221-234.

BUCKUP, PA., 1993. Review of the Characidiinae fishes (Teleostei: Characiformes) with descriptions of four new Genera and ten new species. Ichthyological Exploration of Freshwaters, vol. 4, p. 97-154

BUCKUP, PA., MENEZES, NA. and GHAZZI, MS., 2007. Catálogo das espécies de peixes de água doce do Brasil. Rio de Janeiro: Museu Nacional. 195 p.

CARDOSO, AR. and MALABARBA, LR., 1999. Description of three new species of Hemiancistrus Bleeker, 1862 from southern Brazil (Teleostei: Siluriformes: Loricariidae). Comunicações do Museu de Ciências e Tecnologia da PUCRS, Série Zoologia, vol. 12, p. 141-161.

CARVALHO, FR., 2011. Sistemática de Hyphessobrycon Durbin, 1908 (Ostariophysi: Characidae). Porto Alegre: Universidade Federal do Rio Grande do Sul. 340 p. Tese de Doutorado em Biologia Animal.

CARVALHO, TP. and REIS, RE., 2009. Four new species of Hisonotus (Siluriformes: Loricariidae) from the upper rio Uruguay, southeastern South America, with a review of the genus in the rio Uruguay basin. Zootaxa, no. 2113, p. 1-40.

-, 2011. Taxonomic review of Hisonotus Eigenmann and Eigenmann (Siluriformes: Loricariidae: Hypoptopomatinae) from the laguna dos Patos system, southern Brazil. Neotropical Ichthyology, vol. 9 , no. 1, p. 1-48.

CARVALHO, TP., LEHMANN, P., PEREIRA, EHL. and REIS, RE. 2008. New Species of Hisonotus (Siluriformes: Loricariidae: Hypoptopomatinae) from the Laguna dos Patos Basin, Southern Brazil. Copeia, vol. 2008, no. 3, p. 510-516.

CASATTI, L., 2003. Family Sciaenidae. In REIS, RE., KULLANDER, SO. and FERRARIS JUNIOR, CJ. (Orgs.). Check list of the freshwater fishes of South and Central America. Porto Alegre: Edipucrs. p. 599-602.

COGNATO, D., RICHER-DE-FORGES, MM., ALBERT, JS. and CRAMPTON, WGR., 2009. Gymnotus chimarrao, a new species of electric fish (Gymnotiformes: Gymnotidae) from southern Brazil. Ichthyological Exploration of Freshwaters, vol. 18 , no. 4, p. 375-382.

DUFECH, APS. and FIALHO, CB., 2007. Biologia populacional de Pachyurus bonariensis Steindachner, 1879 (Perciformes, Sciaenidae), uma espécie alóctone no sistema da laguna dos Patos, Brasil. Biota Neotropica, vol. 7, no. 1, p. 91-96.

FERRER, J. and MALABARBA, LR., 2011. A new Trichomycterus lacking pelvic fins and pelvic girdle with a very restricted range in southern Brazil (Siluriformes: Trichomycteridae). Zootaxa, no. 2912 , p. $59-67$

FLORES-LOPES, F., CETRA, M. and MALABARBA, LR., 2010 Utilização de índices ecológicos em assembléias de peixes como instrumento de avaliação da degradação ambiental em programas de monitoramento. Biota Neotropica, vol. 10, no. 4, p. 183-193. http://dx.doi.org/10.1590/S1676-06032010000400024

GUADAGNIN, DL., SOBRAL, M. and BECKER, FG., 1998. A Biodiversidade da Região do Planalto das Araucárias no Rio Grande do Sul: importância, ameaças e recomendações. In 
RICHTER, M. (Org.). A Conservação da Diversidade Biológica e o Desenvolvimento Sustentável em São Francisco de Paula: Plano de Ação Preliminar. Porto Alegre: Edipucrs. p. 79-108.

HASENACK, H. and WEBER, E. (Org.), 2010. Base cartográfica vetorial contínua do Rio Grande do Sul - escala 1:50.000. Porto Alegre: UFRGS, Instituto de Biociências, Centro de Ecologia. 1 DVD-ROM. Série Geoprocessamento, no. 3.

HIRSCHMANN, A., MAJOLO, MA. and GRILLO, HCZ., 2008. Alterações na ictiocenose do rio Forqueta em função da Instalação da Pequena Central Hidrelétrica Salto Forqueta, Putinga, Rio Grande do Sul. Iheringia, Série Zoologia, vol. 98, no. 4, p. 481488. http://dx.doi.org/10.1590/S0073-47212008000400011

LEAL, ME., BREMM, CQ. and SCHULZ, U., 2009. Fish assemblage list of the Sinos river basin, south Brazil. Scientific Journal of Fisheries, Aquaculture and Limnology, vol. 35, no. 2, p. 307-317.

LUZ-AGOSTINHO, KDG., LATINI, JD., ABUJANRA, F., GOMES, LC., AGOSTINHO, AA., 2010. A ictiofauna do rio das Antas: distribuição e bionomia das espécies. Maringá: Clichetec. $115 \mathrm{p}$.

MAJOLO, MA., 2005. Estudo da taxocenose de peixes na ilha do Andrade, bacia hidrográfica do rio Taquari, Arroio do Meio, Rio Grande do Sul, Brasil. Porto Alegre: Universidade Federal do Rio Grande do Sul. 121 p. Dissertação de Mestrado em Biologia Animal.

MALABARBA, LR., 1989. Histórico sistemático e lista comentada das espécies de peixes de água doce do sistema da Laguna dos Patos, Rio Grande do Sul, Brasil. Comunicações do Museu de Ciências e Tecnologia da PUCRS, Série Zoologia, vol. 2, no. 8, p. 107-179.

MALABARBA, LR., FIALHO, CB., ANZA, JA., SANTOS, JF. and MENDES, GN., 2009. Peixes. In BOLDRINI, I. (Org.). Biodiversidade dos Campos do planalto das araucárias. Brasília: MMA. 240 p.

MALABARBA LR. and MAHLER JUNIOR, JKF., 1998. Review of the Genus Microglanis in the rio Uruguay and coastal drainages of southern Brazil (Ostariophysi: Pimelodidae). Ichthyological Exploration of Freshwaters, vol. 9, no. 3, p. 243-254.

MALABARBA, LR. and WEITZMAN, SH., 2003. Description of a new genus with six new species from Southern Brazil, Uruguay and Argentina, with a discussion of a putative characid clade (Teleostei: Characiformes: Characidae). Comunicações do Museu de Ciências e Tecnologia, PUCRS, Série Zoologia, vol. 16, no. 1, p. 67-151.

MELO, FAG. and BUCKUP, PA., 2006. Astyanax henseli, a new name for Tetragonopterus aeneus Hensel, 1870 from southern Brazil (Teleostei: Characiformes). Neotropical Ichthyology, vol. 4, no. 1, p. 45-52.

MENEZES, NA., 2007. Família: Acestrorhynchidae. In BUCKUP, PA., MENEZES, NA. and GHAZZI, MS. (eds.). Catálogo das espécies de peixes de água doce do Brasil. Rio de Janeiro: Museu Nacional. p. 62-63. Série livros, no. 23.

MENEZES, NA. and RIBEIRO, AC., 2010. Oligosarcus jacuiensis (Charciformes: Characidae), a new species from the Uruguay and Jacuí river basins, southern Brazil. Neotropical Ichthyology, vol. 8, no. 3, p. 649-653. http://dx.doi.org/10.1590/S167962252010000300010

MENEZES, NA. and WEITZMAN, SH., 2011. A systematic review of Diapoma (Teleostei: Characiformes: Characidae: Stevardiinae: Diapomini) with descriptions of two new species from southern Brazil. Papéis Avulsos de Zoologia, vol. 51, no. 5, p. 59-82.

NOGUEIRA, C., BUCKUP, PA., MENEZES, NA., OYAKAWA, OT., KASECKER, TP., RAMOS NETO, MB., DA SILVA, J.M.C., 2010. Restricted- range fishes and the conservation Brazilian freshwaters. Plos One, vol. 5, no. 6, e11390, doi:10.1371/journal. pone.0011390 http://dx.doi.org/10.1371/journal.pone.0011390

OTTONI, FP. and CHEFFE, MM., 2009. A new species of Australoheros from the upper rio das Antas, Laguna dos Patos System, southern Brazil (Labroidei, Cichlidae, Cichlasomatinae). Spixiana (München), vol. 32, no. 1, p. 153-159.

OYAKAWA, OT. and MATTOX, GM., 2009. Revision of the Neotropical trahiras of the Hoplias lacerdae species-group (Ostariophysi: Characiformes: Erythrinidae) with descriptions of two new species. Neotropical Ichthyology, vol. 7, no. 2, p. 117-140.

REIS, RE. and CARVALHO, TP., 2007. Hypoptopomatinae. In BUCKUP, PA., MENEZES, NA. and GHAZZI, MS. (Eds.). Catálogo das espécies de peixes de água doce do Brasil. Rio de Janeiro: Museu Nacional. p. 83-84. Série Livros.

REIS, RE., KULLANDER, SO. and FERRARIS-JUNIOR, CJ., 2003a. Check-list of the freshwater fishes of South and Central America. Porto Alegre: Edipucrs. 742 p.

REIS, RE., LUCENA, ZMS., LUCENA, CAS. and MALABARBA, LR., 2003b. Peixes. In FONTANA, CS., BENCKE, GA. and REIS, RE (Eds.). Livro vermelho da fauna ameaçada de extinção no Rio Grande do Sul. Porto Alegre: Edipucr. p. 117-146.

RIBEIRO, MF. and KÖHLER, A., 2007. Ictiofauna do rio Pardinho. Caderno de Pesquisa. Série Biologia (UNISC), vol. 19, no. 2 , p. $37-45$.

RICAN, O. and KULLANDER, SO., 2006. Character - and tree - based delimitation of species in the "Cichlasoma" facetum group (Teleostei, Cichlidae) with the description of a new genus. Journal of Zoological Systematics and Evolutionary Research, vol. 44, no. 2, p. 136-152. http://dx.doi.org/10.1111/j.14390469.2005.00347.x

RODRIGUEZ, MS. and REIS, RE., 2008. Taxonomic review of Rineloricaria (Loricariidae: Loricariinae) from the Laguna dos Patos drainage, southern Brazil, with the descriptions of two new species and the recognition of two species groups. Copeia, vol. 2008, no. 2, p. 333-349.

Rio Grande do Sul. Governo do Estado. Secretaria Estadual do Meio Ambiente. 2007. Relatório Anual sobre a Situação dos Recursos Hídricos no Estado do Rio Grande do Sul, 2006. Porto Alegre: SEMA/DRH. 71 p. Disponível em: http://www.sema. rs.gov.br/upload/Relatorio_RH_Final_2006.pdf

SACCOL-PEREIRA, A., MILANI, PCC. and FIALHO, CB., 2006. Primeiro registro de Acestrorhynchus pantaneiro Menezes, 1992 (Characiformes, Acestrorhynchidae) no sistema da laguna dos Patos, Rio Grande do Sul, Brasil. Biota Neotropica, vol. 6, p. 1-4. http://dx.doi.org/10.1590/S1676-06032006000300017

SILVA, JFP., 2004. Two new species of Bryconamericus Eigenmann (Characiformes: Characidae) from southern Brazil. Neotropical Ichthyology, vol. 2, no. 2, p. 55-60.

SOUZA-LIMA, R., 2007. Família Characidae: Aphyocharacinae. In BUCKUP, PA., MENEZES, NA. and GHAZZI, MS. (Eds.). Catálogo das espécies de peixes de água doce do Brasil. Rio de Janeiro: Museu Nacional. p. 32-33. Série livros, no. 23.

STRAHLER, AN., 1957. Quantitative analysis of watershed geomorphology. Transactions - American Geophysical Union, vol. 38, p. 913-920. http://dx.doi.org/10.1029/TR038i006p00913

VARI, RP. and MALABARBA, LR., 1998. Neotropical ichthyology: an overview. In MALABARBA, LR., REIS, RE., VARI, RP., LUCENA, ZMS. and LUCENA, CAS. (Eds.). Phylogeny and classification of Neotropical fishes. Porto Alegre: Edipucrs. p. 1-12.

WILEY, EO. and JOHNSON, GD., 2010 A teleost classification based on monophyletic groups. In NELSON, JS., SCHULTZE, H-P. and WILSON, MVH. (Eds.). Origin and Phylogenetic Interrelationships of Teleosts. München: Verlag Dr. Friedrich Pfeil. p. 123-182. 